\title{
Pengaruh Kurs Dolar, Indeks Dow Jones Dan Tingkat Suku Bunga SBI Terhadap IHSG (Periode Januari 2005 - Januari 2015)
}

\author{
Rihfenti Ernayani \\ Program Studi Akuntansi Fakultas Ekonomi Universitas Balikpapan \\ Jl. Pupuk Raya PO BOX 335 Balikpapan. Telp./Fax. 0542-764205 \\ Email :rihfenti@yahoo.co.id
}

\begin{abstract}
The capital market is one of the investment alternatives for investors. Investors who are willing to invest in the stock market can invest in the Indonesian Stock Exchange (BEI). One index that is often overlooked by investors when they invest in the Indonesia Stock Exchange is the Composite Stock Price Index (CSPI), because through the movement of the Composite Stock Price Index, the investors can see whether market conditions are excited or lethargic. Some things that need to be considered by investors in investing is the exchange rate of the dollar, dow jones index and the interest rate of the certificate of Bank Indonesia. This study aims to test and prove empirically the effect of the dollar exchange rate, the Dow Jones index, and the interest rate of the certificate of Bank Indonesia upon the composite stock price index during the period January 2005 to January 2015. The sampling technique used in this study is purposive sampling with the number of the data processed as many as 121. the data analyzed is conducted by means of multiple linear regression method.

The results show that the variables of Dollar exchange rate, Dow Jones, and the Interest Rate of Bank Indonesia Certificate simultaneously affect the Composite Stock Price Index (CSPI), whereas in partial the Dollar exchange rate does not affect the Composite Stock Price Index. Dow Jones Index has a positive influence on the Composite Stock Price Index and the rate of interest Bank Indonesia Certificate negatively affects the Composite Stock Price Index. One of the three variables that has the greatest influence or dominant on the Composite Stock Price Index is the Dow Jones index.
\end{abstract}

Key words : Composite Stock Price Index (CSPI), Dollar Exchange Rate, Dow Jones Index, The Interest rate of Bank Indonesia Certificate

\begin{abstract}
Abstrak
Pasar modal merupakan salah satu alternatif investasi bagi para investor.Investor yang ingin berinvestasi di pasar modal dapat berinvestasi di Bursa Efek Indonesia (BEI). Salah satu indeks yang sering diperhatikan investor ketika berinvestasi di Bursa Efek Indonesia adalah Indeks Harga Saham Gabungan (IHSG), karena melalui pergerakan Indeks Harga Saham Gabungan investor dapat melihat kondisi pasar apakah sedang bergairah atau lesu. Beberapa hal yang perlu diperhatikan oleh investor dalam berinvestasi adalah mengenai kurs dolar, indeks dow jones dan tingkat suku bunga sertifikat Bank Indonesia (SBI). Penelitian ini bertujuan untuk menguji dan membuktikan secara empirik pengaruh kurs dolar, indeks Dow Jones dan tingkat suku bunga Sertifikat Bank Indonesia terhadap indeks harga saham gabungan selama periode Januari 2005 sampai dengan Januari 2015. Teknik pengambilan sampel dalam penelitian ini menggunakan purposive sampling dengan jumlah data yang diolah sebanyak 121.Data dianalisa dengan menggunakan metode regresi linier berganda. Hasil penelitian menunjukkan bahwa variabel Kurs Dolar, Indeks Dow Jones dan Tingkat Suku Bunga Sertifikat Bank Indonesia (SBI) secara simultan berpengaruh terhadap Indeks Harga Saham Gabungan (IHSG), sedangkan secara parsial variabel Kurs Dolar tidak berpengaruh terhadap Indeks Harga Saham Gabungan, variabel Indeks Dow Jones berpengaruh positif terhadap Indeks Harga Saham Gabungan dan variabel Tingkat Suku Bunga SBI berpengaruh negatif terhadap Indeks Harga Saham Gabungan. Variabel yang memiliki pengaruh paling besar atau dominan terhadap Indeks Harga Saham Gabungan adalah Indeks Dow Jones.
\end{abstract}

Kata kunci : IHSG, Kurs Dolar, Indeks Dow Jones, Tingkat Suku Bunga SBI 


\section{Pendahuluan}

Pasar modal (capital market) merupakan pasar untuk berbagai intrumen keuangan jangka panjang yang bisa diperjualbelikan, baik dalam bentuk utang maupun modal sendiri.Instrumeninstrumen keuangan yang diperjualbelikan di pasar modal seperti saham dan obligasi.Pasar modal merupakan salah satu alternatif investasi bagi para investor.

Investor yang berminat untuk berinvestasi di pasar modal dapat berinvestasi di Bursa Efek Indonesia (BEI).Untuk memberikan informasi yang lebih lengkap bagi para investor tentang perkembangan bursa, Bursa Efek Indonesia menyebarkan data pergerakan harga saham melalui media cetak dan elektronik.Satu indikator pergerakan harga saham tersebut adalah indeks harga saham.Salah satu indeks yang sering diperhatikan investor ketika berinvestasi di Bursa Efek Indonesia adalah Indeks Harga Saham Gabungan.Hal ini disebabkan indeks ini berisi atas seluruh saham yang tercatat di Bursa Efek Indonesia.Oleh karena itu melalui pergerakan Indeks Harga Saham Gabungan, sebagai investor dapat melihat kondisi pasar apakah sedang bergairah atau lesu.Perbedaan kondisi pasar ini tentu memerlukan strategi yang berbeda dari investor dalam berinvestasi.

Bagi perusahaan-perusahaan yang aktif melakukan kegiatan ekspor dan impor kestabilan nilai kurs mata uang dolar terhadap rupiah menjadi hal yang penting, sebab ketika nilai rupiah terdepresiasi dengan dolar Amerika Serikat, hal ini akan mengakibatkan barang-barang impor menjadi mahal. Apabila sebagian besar bahan baku perusahaan menggunakan bahan impor, secara otomatis ini akan mengakibatkan kenaikan biaya produksi. Kenaikan biaya produksi ini tentunya akan mengurangi tingkat keuntungan perusahaan. Turunnya tingkat keuntungan perusahaan tentu akan mempengaruhi minat beli investor terhadap saham perusahaan yang bersangkutan. Secara umum, hal ini akan mendorong pelemahan indeks harga saham di negara tersebut.

Selain itu salah satu variabel ekonomi yang dapat digunakan untuk mengukur kinerja perekonomian suatu negara adalah indeks saham di negara tersebut.Untuk Amerika Serikat indeks yang dapat dijadikan proksi adalah Indeks Dow Jones.Indeks Dow Jones merupakan indeks pasar saham tertua di Amerika Serikat dan merupakan representasi dari kinerja industri terpenting di Amerika Serikat.Perusahaan yang tercatat di Indeks Dow Jones pada umumnya merupakan perusahaan multinasional.Kegiatan operasi mereka tersebar di seluruh dunia.Indeks Dow Jones yang bergerak naik, menandakan kinerja perekonomian Amerika Serikat secara umum berada pada posisi yang baik. Dengan kondisi perekonomian yang baik, akan menggerakkan perekonomian Indonesia melalui kegiatan ekspor maupun melalui pasar modal (Sunariyah, 2006). Aliran modal yang masuk melalui pasar modal tentu akan memiliki pengaruh terhadap perubahan Indeks Harga Saham Gabungan. Demikian pula dengan tingkat suku bunga sertifikat Bank Indonesia.Kebijakan tingkat suku bunga di Indonesia dikendalikan secara langsung oleh Bank Indonesia melalui BI rate. BI Rate merupakan respon bank sentral terhadap tekanan inflasi ke depan agar tetap berada pada sasaran yang telah ditetapkan. Perubahan BI rate secara otomatis akan memicu penurunan tingkat suku bunga kredit maupun deposito. Bagi para investor dengan penurunantingkat suku bunga deposito, akan mengurangi tingkat keuntungan yang diperoleh bila dana yang mereka miliki diinvestasikan dalam bentuk deposito. Selain itudengan penurunan suku bunga kredit, biaya modal akan menjadi kecil, ini dapat mempermudah perusahaan untuk memperoleh tambahan dana dengan biaya yang murah untuk meningkatkan produktivitasnya. Peningkatan produktivitas akan mendorong 
peningkatan laba, hal ini dapat menjadi daya tarik bagi para investor untuk berinvestasi di pasar modal.

Berdasarkan uraian tersebut diatas, maka rumusan masalah dalam penelitian ini adalah "Apakah Kurs Dolar, Indeks Dow Jones dan Tingkat Suku Bunga Sertifikat Bank Indonesia (SBI) berpengaruh terhadap Indeks Harga Saham Gabungan (IHSG)?'Tujuan yang ingin dicapai dalam penelitian ini adalah untuk mendapatkan bukti empiris apakah variabel kurs dolar,Indeks Dow Jonesdan tingkat suku bunga Bank Indonesia mempunyai pengaruh terhadap Indeks Harga Saham Gabungan.

\section{Telaah Literatur Dan Perumusan Hipotesis Nilai Tukar (Kurs)}

Kurs adalah harga suatu mata uang yang dinyatakan dalam mata uang lain (Siamat, 2004). Kurs merupakan salah satu indikator yang mempengaruhi aktivitas dipasar saham maupun di pasar uang karena investor cenderung akan berhatihati untuk melakukan investasi portofolio. Terdepresiasinya kurs rupiah terhadap mata uang asing khususnya dolar Amerika memiliki pengaruh yang negatif terhadap ekonomi dan pasar modal.Samsul (2008), perubahan satu variabel makro ekonomi memiliki dampak yang berbeda terhadap harga saham, yaitu suatu saham dapat terkena dampak positif sedangkan saham lainnya terkena dampak negatif.

\section{Indeks Dow Jones}

Indeks Dow Jones merupakan indeks pasar saham tertua di Amerika.selain indeks transportasi Dow Jones. Indeks Dow Jones merupakan salah satu dari 3 indeks utama di Amerika Serikat.Naiknya Indeks Dow Jones ini berarti kinerja perekonomian Amerika Serikat ikut membaik. Sebagai salah satu negara tujuan ekspor Indonesia, pertumbuhan ekonomi Amerika Serikat dapat mendorong pertumbuhan ekonomi Indonesia melalui kegiatan ekspor maupun modal masuk baik investasi langsung maupun melalui pasar modal.

\section{a. Tingkat Suku Bunga Sertifikat \\ Bank Indonesia (SBI)}

Tingkat suku bunga merupakan salah satu faktor penting yang perlu diperhatikan dalam pembuatan keputusan investasi.Dornbusch, et al, (2008) tingkat suku bunga merupakan tingkat pembayaran bunga tahunan dari suatu pinjaman yang diperoleh dari jumlah bunga yang diterima tiap tahun dibagi dengan jumlah pinjaman.Suku bunga adalah pembayaran yang dilakukan untuk penggunaan uang, atau jumlah bunga yang harus dibayar per unit waktu. Berdasarkan Surat Edaran Bank Indonesia NO.8/13/DPM tentang Penerbitan Sertifikat Bank Indonesia melalui lelang, Seritifikat Bank Indonesia yang selanjutnya disebut SBI adalah surat berharga dalam mata uang rupiah yang diterbitkan oleh Bank Indonesia sebagai pengakuan utang berjangka waktu pendek. Sebagai otoritas moneter, Bank Indonesia berkewajiban memelihara kestabilan nilai rupiah.

\section{b. Indeks Harga Saham Gabungan (IHSG)}

Indeks harga saham

membandingkan perubahan harga saham dari waktu ke waktu, sehingga akan terlihat apakah suatu harga saham mengalami penurunan atau kenaikan dibandingkan dengan suatu waktu tertentu. Indeks Harga Saham Gabunganatau Composite Stock Price Index (IHSG) merupakan suatu nilai yang digunakan untuk mengukur kinerja gabungan seluruh saham yang tercatat di suatu bursa efek.Indeks Harga Saham Gabungan seluruh saham menggambarkan suatu rangkaian informasi historis mengenai pergerakan harga saham gabungan seluruh saham, sampai pada tanggal tertentu (Sunariyah, 2006).Biasanya pergerakan harga saham tersebut disajikan setiap hari, berdasarkan harga penutupan di bursa pada hari tersebut.Indeks tersebut disajikan untuk periode tertentu. 
Berdasarkan pada kajian diatas, dapat dirumuskan hipotesis sebagai berikut: "Kurs Dolar, Indeks Dow Jones dan Tingkat Suku Bunga SBI berpengaruh terhadap Indeks Harga Saham Gabungan (IHSG)".

\section{Metode Penelitian \\ Definisi Operasional dan Pengukuran Variabel}

Indeks Harga Saham Gabungan (IHSG) (Y).IHSG adalah indeks harga saham gabungan yang dikeluarkan oleh Bursa Efek Indonesia setiap hari.Kurs Dolar $\left(\mathbf{X}_{1}\right)$.Kurs yang digunakan adalah kurs dolar Amerika terhadap kurs tengah rupiah yang dikeluarkan oleh Bank Indonesia.Indeks Dow Jones $\left(\mathbf{X}_{2}\right)$.Merupakan indeks yang dapat digunakan untuk mengukur performa kinerja perusahaan yang bergerak di sector industri di Amerika Serikat.Indeks Dow Jones terdiri atas 30 perusahaan besar dan terkemuka di Amerika Serikat.Data yang digunakan adalah data bulanan dari Januari 2005 sampai Januari 2015.Tingkat Suku Bunga SBI $\left(\mathbf{X}_{3}\right)$.Tingkat suku bunga yang dikeluarkan oleh Bank Indonesia pada akhir bulan sesuai keputusan dengan rapat dewan Gubernur.Data yang digunakan adalah data tiap akhir bulan selama periode amatan bulan Januari 2005 sampai dengan Januari 2015.

\section{Pemilihan Sampel dan Pengumpulan Data}

Populasi dalam penelitian ini adalah seluruh data indeks harga saham gabungan (IHSG) sejak bursa efek Indonesia didirikan. Data yang digunakan dalam penelitian ini adalah data IHSG, Kurs Dolar Amerika,Indeks Dow Jones, Tingkat Suku Bunga SBI, yang dibatasi pada data bulanan periode Januari 2005 sampai dengan Januari 2015. Penarikan sampel dilakukan dengan metode purposive sampling, dengan masing-masing data adalah sebanyak 121.

\section{Model Analisis}

Untuk menguji hipotesis digunakan model alisis statistic regresi linier berganda yang secara statistic persamaannya adalah sebagai berikut :

$$
Y=a+b_{1} X_{1}+b_{2} X_{2}+b_{3} X_{3}+e i
$$

Keterangan :

$\mathrm{Y}=$ Indeks Harga Saham Gabungan (IHSG), a= Nilai intercept atau konstanta, b1, b2, b3= Koefisien regresi, yaitu besarnya perubahan $\mathrm{Y}$ apabila $\mathrm{X}$ berubah sebesar satu satuan, $X_{1}=$ Kurs Dolar, $X_{2}=$ Indeks dow jones, $\mathrm{X} 3=$ Tingkat Suku Bunga SBI, ei= standar error.

\section{Teknik Analisis Data}

Pengujian hipotesis penelitian menggunakan metode analis regresi linier berganda dengan bantuan program SPSS 22.0 for windows, sedangkan teknik analisis yang digunakan meliputi: (1) uji asumsi klasik yaitu untuk menguji kelayakan penggunaan model regresi (Ghozali, 2007). Uji asumsi klasik terdiri dari uji multikolinearitas, uji heteroskedastitas dan uji autokorelasi. (2) metode regresi berganda yang meliputi uji $\mathrm{t}$ (parsial) dan uji F (simultan).

\section{Hasil Dan Pembahasan}

Berdasarkan hasil olahan SPSS diperoleh persamaan regresi linier berganda sebagai berikut:

$$
\begin{gathered}
Y=776,766+0,067 X_{1}+0,362 X_{2}- \\
3_{376,495} X_{3}+e
\end{gathered}
$$

\section{Pengujian}

\section{Pengujian Asumsi Klasik}

Dalam penggunaan analisis regresi linier bergandaperlu diketahui apakah pengunaan model regresi linierberganda tersebut telah memenuhi syarat asumsiasumsiklasik untuk menguji kelayakan terhadap model yang digunakan.Berdasarkan hasil pengujian didapat hasil bahwa regresi linier berganda layak untuk di gunakan karena tidak menyimpang dari asumsi-asumsi klasik.

\section{Pengujian Simultan (Uji-F)}

Hasil uji $F$ regresi berganda pada tabel diatas, diperoleh nilai $F_{\text {hitung }}=$ 237.618 pada taraf signifikansi $\alpha=0,000$ 
lebih besar daripada $\mathrm{F}_{\text {tabel }}=2,68$ taraf signifikansi $\alpha=0,05$ sehingga Ho ditolak danH $_{1}$ diterima. Hal ini berarti bahwa Kurs Dolar $\left(\mathrm{X}_{1}\right)$, Indeks Dow Jones $\left(\mathrm{X}_{2}\right)$, Tingkat Suku Bunga SBI $\left(\mathrm{X}_{3}\right)$ secara bersama-samamempunyai pengaruh yangsignifikan terhadap IHSG. Dengan demikian, hipotesis yang menyatakan bahwa Kurs Dolar $\left(\mathrm{X}_{1}\right)$, Indeks Dow Jones $\left(\mathrm{X}_{2}\right)$, Tingkat Suku Bunga SBI $\left(\mathrm{X}_{3}\right)$ secara bersama-sama mempunyai pengaruh yang berartiterhadap IHSG, telah terbuktidan dapat diterima kebenarannya.

\section{Pengujian Parsial (t-test)}

Berdasarkan data diatas, maka hipotesis yang menyatakan bahwa Indeks Dow Jones $\left(\mathrm{X}_{2}\right)$ dan Tingkat Suku Bunga $\operatorname{SBI}\left(X_{3}\right)$ secara parsial mempunyai pengaruh signifikan dibandingkan variabelKurs Dolar $\left(\mathrm{X}_{1}\right)$, terbukti dan dapat diterima kebenarannya.

\section{Pengaruh Kurs Dolarterhadap IHSG}

Pengaruh variabel Kurs

Dolarterhadap IHSG dapat dilihat dari koefisien regresinya. Dalam persamaan regresi berganda diatas tampak bahwa variabel Kurs Dolar $\left(\mathrm{X}_{1}\right)$ memiliki hubungan yang positif tetapi tidak signifikan terhadap IHSG (Y). Secara parsial, jika ada peningkatan skor Kurs Dolar $\left(\mathrm{X}_{1}\right)$ sebesar satu satuan, maka padarata-ratanya akan meningkatkan skor IHSGsebesar koefisien regresi $b_{1}=0,067$, dengan asumsi variabel bebas Indeks Dow Jones $\left(\mathrm{X}_{2}\right)$, Tingkat Suku Bunga SBI $\left(\mathrm{X}_{3}\right)$ dalam keadaan tetap (ceteris paribus).

Berdasarkan hasil perhitungan tersebut, maka hipotesis yang diajukan dalam penelitian ini tidak terbukti, yaitu kus dolar tidak berpengaruh terhadap IHSG.Hasil dari penelitian ini berbeda dengan hasil penelitian yang dilakukan oleh Handayani (2007) yang menyimpulkan bahwa kurs dolar berpengaruh positif signifikan terhadap indeks harga saham gabungan.Mansur (2009) mengemukakan hasil penelitiannya bahwa kurs dolar berpengaruh signifikan namun dengan arah negative. Apabila rupiah terdepresiasi terhadap dolar Amerika maka indeks harga saham gabungan cenderung akan melemah dan begitu sebaliknya, apabila rupiah terapresiasi terhadap dolar maka indeks harga saham gabungan akan mengalami penguatan.

\section{Pengaruh Indeks Dow Jones terhadap IHSG}

Pengaruh variabel Indeks Dow Jones terhadap IHSG, dapat dilihat dari koefisien regresinya. Dalam persamaan regresi berganda diatas tampak bahwa variabelIndeks Dow Jones $\left(\mathrm{X}_{2}\right)$, memiliki hubungan yang positif terhadapIHSG. Hal ini berarti setiap ada peningkatanIndeks Dow JonesmakaIHSG juga akan mengalami peningkatan. Secara parsial, jika ada peningkatan skor Indeks Dow Jones $\left(\mathrm{X}_{2}\right)$ sebesar satu, maka padarata-ratanya akan meningkatkan skor IHSGsebesar koefisien regresi $b_{2}=0,362$, dengan asumsi variabel bebas variabel Kurs Dolar $\left(\mathrm{X}_{1}\right)$, Tingkat Suku Bunga SBI $\left(\mathrm{X}_{3}\right)$ dalam keadaan tetap (ceteris paribus).Berdasarkan hasil perhitungan tersebut, maka hipotesis yang diajukan dalam penelitian ini terbukti, yaitu indeks dow jones berpengaruh positif terhadap IHSG. Hal ini dilatarbelakangikarena Amerika Serikat merupakan negara tujuan ekspor utama Indonesia (www.bi.go.id),sehingga perubahan kondisi perekonomian Amerika Serikatyang akan tercermin di Indeks Dow Jones akan memberikan pengaruh bagiperekonomian Indonesia melalui IHSG.Hasil dari penelitian ini memperkuat penelitian yang dilakukan oleh Muharram (2008) dimana indeks Dow Jones memiliki pengaruhyang positif terhadap Indeks Harga Saham Gabungan.Prakarsa (2008) dalam penelitiannya menyimpulkan bahwa Indeks Dow Jones memiliki pengaruh terhadap Indeks Harga Saham Gabungan. Ruhendi dan Arifin (2003) menyimpulkan bahwa indeks dow jones mempunyai pengaruh yang signifikan terhadap indeks harga saham gabungan.

\section{Pengaruh Tingkat Suku Bunga SBI terhadap IHSG}


Pengaruh variabelTingkat Suku Bunga SBI $\left(\mathrm{X}_{3}\right)$ terhadap IHSG, dapat dilihat dari koefisien regresinya. Dalam persamaan regresi berganda diatas tampak bahwa variabel Tingkat Suku BungaSBI $\left(\mathrm{X}_{3}\right)$, memiliki hubungan yangnegative terhadapIHSG. Hal ini berarti setiap ada peningkatanSBI, makaIHSG akan mengalami penurunan. Secara parsial, jika ada peningkatan skor Tingkat Suku Bunga $\mathrm{SBI}\left(\mathrm{X}_{3}\right)$ sebesar satu, maka padarata-ratanya akan menurunkan skor IHSGsebesar koefisien regresi $b_{2}=$ 376.495, dengan asumsi variabel bebas Kurs Dolar $\left(\mathrm{X}_{1}\right)$, Indeks Dow Jones $\left(\mathrm{X}_{2}\right)$ dalam keadaan tetap (ceteris paribus), sedangkan jika semua variabel bebas secara bersama-sama dalam keadaan tetap, maka pada rata-ratanyaIHSGmempunyai nilai skor sama dengan koefisien intersep (konstanta) sebesar bo $=-198.520$, artinya berbanding terbalik dikarenakan dalam keadaan minus (-).Berdasarkan hasil tersebut, maka hipotesis yang diajukan dalam penelitian ini terbukti, yaitu Tingkat Suku Bunga SBI berpengaruh terhadap IHSG, walaupun arahnya negative. Perubahan tingkat suku bunga SBI akan memberikan pengaruh bagi pasar modal dan pasar keuangan. Apabila tingkat suku bunga naik maka secara langsung akan meningkatkan beban bunga. Perusahaan yang mempunyai leverage yang tinggi akan mendapatkan dampak yang sangat berat terhadap kenaikan tingkat bunga. Kenaikan tingkat bunga ini dapat mengurangi profitabilitas perusahaan sehingga dapat memberikan pengaruh terhadap harga saham perusahaan yang bersangkutan, yang secara langsung dapat mempengaruhi indeks harga saham gabungan.Hasil penelitian ini memperkuat hasil penelitian dari Chiarella dan Gao (2004), Handayani (2007), Kandir (2008) dan Murwaningsari (2008) yang membuktikan bahwa tingkat suku bunga SBI berpengaruh negative terhadap IHSG. Namun hasil penelitian ini berbeda dengan penelitian yang dilakukan oleh Prakarsa (2008), Mansur (2009), Kewal (2012) dan
Krisna (2013) yang menyimpulkan bahwa tingkat suku bunga SBI tidak memiliki pengaruh terhadap IHSG.

\section{Kesimpulan Dan Saran}

Variabel Kurs Dollar, Indeks Dow Jones dan Tingkat Suku Bunga SBI secara simultan berpengaruh terhadap Indeks Harga Saham Gabungan (IHSG).Secara parsial variabel Kurs Dollar tidak berpengaruh terhadap Indeks Harga Saham Gabungan, variabel Indeks Dow Jones berpengaruh positif terhadap Indeks Harga Saham Gabungan, variabel Tingkat Suku Bunga Sertifikat Bank Indonesia (SBI) berpengaruh negatif terhadap Indeks Harga Saham Gabungan (IHSG).Bagi investor yang hendak berinvestasi di Bursa Efek Indonesia, hendaknya memperhatikan pergerakan keempat variabel tersebut, sebab berdasarkan perhitungan diperoleh nilai adjusted $\mathrm{R}$ square adalah sebesar 0,855 ini berarti bahwa variasi dari variabel independen yang digunakan dalam penelitian ini mampu menjelaskan $85,5 \%$ variasi variabel dependen. Ini berarti pergerakan Indeks Harga Saham Gabungan dapat diprediksi dari pergerakan ketiga variabel independen tersebut.

\section{Daftar Pustaka}

Ang, Robert, 1997, "Buku Pintar : Pasar Modal Indonesia”, First Edition, Mediasoft Indonesia

Chiarella C. and Gao.S, 2004." The value of the S\&P $500-A$ Macro View of The Stock market Adjustment Process". Global Finance Journal, 15: 171-196.

Donbusch, R.,Fisher, S and Richard Starz. 2008. Makro Ekonomi. Terjemahan oleh Roy Indra Mirazudin, Jakarta PT Media Global Edukasi.

Gjerde, Oystein \& Frode Saettem, (1999). "Causal Relations Among Stock Returns and Macroeconomic Variables in 
A Small, Open Economy". Journal of International Financial Markets, Institutions and Money, 9:61-74.

Ghozali, Imam. 2007. Aplikasi Analisis Multivariate Dengan Program SPSS. Penerbit Undip, Semarang.

Gujarati, Damodar N. 2003. Basic Econometrics. $4^{\text {th }} \quad$ Edition.McGraw-Hill, hal 248.

Handayani, 2007. “ Pengaruh Tingkat Suku Bunga SBI, Nilai Kurs Dolar AS dan Tingkat Inflasi Terhadap Indeks Harga Saham Gabungan", Jurnal Keuangan dan Bisnis, Vol. 5 No.1 maret 2007, Hal 55-67.

Hooker, M.A. 2004. Macroeconomic Factors and Emereing Market Equity Return: A Bayesian Model Selection Approach. Journal Emerging Markets Review 5:379-387.

Ikatan Akuntan Indonesia, 2007, Standar Akuntansi Keuangan, Jakarta : Salemba Empat.

Jose, Rizal Joesoef, 2007. Pasar Uang dan Pasar Valuta Asing, Salemba Empat, Jakarta.

Kandir, S.Y. 2008.Macroeconomic Variabels, Firm Characteritics and Stock Returns : Evidence from Turkey. International Research Journal of Finance and Economics.ISSN 1450-2887 Issue 16.

Kewal, S.S, 2012. Pengaruh Inflasi, Suku Bunga, Kurs dan pertumbuhan GDP terhadap IHSG.Jurnal Economia Volume 8 No. 1, April. Hal 53-64.

Krisna, Anak Agung Gde Aditya. 2013. Pengaruh Inflasi, Nilai Tukar Rupiah, Suku Bunga SBI pada Indeks Harga Saham Gabungan Di BEI. Jurnal Akuntansi Universitas Udayana 3.2 : 421435.
Kuncoro, M. 2003. Metode Riset untuk Bisnis \& Ekonomi.Jakarta : Penerbit Erlangga, hal 218.

Markus, Bodie, Kane. 2004. Investment $5^{\text {th }}$ edition. Mc Graw Hill.

Mok, H. M, 1993. Causality of Interest Rate, Exchange rate and Stock Price at Stock Market Open and Close in Hongkong. Asia Pacific Journal of Management.Vol X hal 123-129.

Muharam, Harjum, 2008. "Analisis pengaruh nilai tukar rupiah dan indeks jow jones terhadap indeks harga saham gabungan”.Jurnal Maksi Volume 8 No 1 Januari 2008: 24-42. FE Universitas Dipenogoro, Semarang.

Murwaningsari, Etty, 2008. Pengaruh Volume Perdagangan, Tingkat Suku Bunga SBI (Deposito) dan Kurs terhadap IHSG beserta Prediksi IHSG, Jurnal Ekonomi dan Bisnis Indonesia, Volume 23 No 2, April 2008. 178-195, FE Universitas Trisakti, Jakarta.

Nasry, Amir, 2003. Globalization Effect on Stock Exchange Integration. Available: www.proquest.com

Prakarsa, Tegarief Ocki, 2008. Analisis Pengaruh Tingkat Suku Bunga SBI, Kurs tengah BI, Tingkat Inflasi dan Indeks Saham Dow Jones Di New York Stock Exchange Dalam Memprediksi Indeks Harga Saham Gabungan di Bursa Efek Jakarta. Jurnal Ekonomi/Tahun XIII No.03, November: 305-318.

Ruhendi \& Arifin, Johan. 2003. Dampak Perubahan Kurs Rupiah dan Indeks Saham Dow Jones di New York Stock Exchange Terhadap Indeks Harga Saham Gabungan di BEJ. Jurnal Wahana Vol. 6 hal 45-55. 
Samsul, Mohammad, 2008. Pasar Modal dan Manajemen Portofolio. Erlangga, Jakarta

Santoso, Singgih. 2001. Pengolahan Data dengan SPSS.Jakarta : PT Elex Media Komputindo, hal 217-254.

Slamat, Dahlan (2004), Manajemen Lembaga Keuangan, Jakarta Fakultas Ekonomi Universitas Indonesia.
Sulaiman, Wahid, 2002. Jalan Pintas menguasai SPSS 10.0, Penerbit Andi, Yogyakarta..

Wongbangpo, Praphan dan Subhash C. Sharma. 2002. "Stock Market and Macroeconomic Fundamental Dynamic Interaction, ASEANi5 Countries". Journal of Asian Economic 13:27-51. 